\title{
Yield and nutrient content of tomato (Solanum lycopersicum L.) as influenced by Trichoderma harzianum and Glomus mosseae inoculation
}

\author{
${ }^{1}$ Bombiti Nzanza*, ${ }^{1}$ Diana Marais and ${ }^{2}$ Puffy Soundy \\ ${ }^{1}$ Department of Plant Production and Soil Science, Faculty of Natural and Agricultural Sciences, \\ University of Pretoria, Private Bag X20, Hatfield, 0028, South Africa \\ ${ }^{2}$ Department of Crop Sciences, Faculty of Science, Tshwane University of Technology, Private \\ Bag X680, Pretoria, 0001, South Africa
}

\begin{abstract}
Recent trends in soil microbiology suggest that fungal inoculants such as Trichoderma harzianum or arbuscular mycorrhizal fungi (AMF) have the potential to improve yield and fruit quality of crops. The purpose of this study was to investigate the effect of inoculating tomato (Solanum lycopersicum L.) with T. harzianum and the AMF (Glomus mosseae) on yield and nutrient content of tomato fruit. A factorial experiment $(3 \times 3)$ with three application timings for each of T. harzianum and AMF, namely uninoculated control, inoculated before sowing and two weeks after sowing, giving nine treatment combinations was conducted in a greenhouse. Both $T$. harzianum and AMF increased total yield and marketable yield of tomato $(\mathrm{P}>0.05)$. Inoculating tomato with AMF before sowing significantly increased the percentage of extra-large fruit, while inoculation with $T$. harzianum two weeks after sowing lowered the $\mathrm{Ca}$ and $\mathrm{Mg}$ contents of tomato fruit. Trichoderma harzianum and AMF inoculation increased the lycopene content, but did not affect the antioxidant activity, total flavonoids or vitamin $\mathrm{C}$ of the tomato fruit. Results of this study suggested that $T$. harzianum and AMF have the potential to influence yield and nutrient content of tomato in a greenhouse.
\end{abstract}

Keywords: Mycorrhizae; nutrient uptake; phytochemical content; Solanum lycopersicum; Trichoderma harzianum 


\section{Introduction}

Tomato is the second-most important vegetable in the world after potato (Dorais et al., 2008), with a worldwide production of 129 million tons in 2008 (FAO, 2010). It is an excellent source of health-promoting compounds due to the balanced mixture of antioxidants including vitamins $\mathrm{C}$ and $\mathrm{E}$, lycopene, beta-carotene, lutein and flavonoids (Dorais et al., 2008), amino acids, proteins, fatty acids and carbohydrates (Hauffman and Bruce, 2002; Heeb, 2005). Tomato is also rich in macronutrients, especially $\mathrm{K}$ (Wilcox et al., 2003; Odriozola-Serrano et al., 2009), P, Mg and Ca (Suárez et al., 2008) and contains high amounts of trace elements such as Fe, Mn, $\mathrm{Zn}$, and $\mathrm{Cu}$ (Ahmed et al., 2010). Nutritional studies have suggested that regular consumption of fruits and vegetables, including tomatoes, can play an important role in preventing cancer and cardiovascular diseases in humans (Heber, 2000; Rao and Agarwal, 2000, Toor and Savage, 2005).

Since tomato fruit play an important role in human health (Chapagain and Wiesman, 2004), strategies for increasing fruit production and quality are of great interest to producers (Gruda, 2005; Flores et al., 2010). Compelling evidence in literature suggest that mineral nutrients can affect the antioxidant content of tomato fruit and overall tomato fruit quality. For instance, increased $\mathrm{Ca}$ levels in soil solution increase $\mathrm{Ca}$ content in tomato fruit, but decrease carotene content and lycopene levels (Paiva et al., 1998). Adequate Ca supply is essential for fruit firmness and extended shelf life (Cooper and Bangerth, 1976). Increasing K increases carotenoid concentration, particularly the lycopenes (Trudel and Ozbun, 1971). According to Mozafar (1994), beta-carotene content in fruit increases with increasing levels of $\mathrm{K}, \mathrm{Mg}, \mathrm{Mn}, \mathrm{B}, \mathrm{Cu}$ and Zn, whereas Lester (2006) reported that ascorbic acid increased with increasing levels of K, Mn, $\mathrm{B}, \mathrm{Cu}$ and $\mathrm{Zn}$. Phosphorus may also increase the fruit concentration of phytochemicals such as ascorbic acid, flavonoids and lycopene (Dorais et al., 2008). The need for producing of high quality food, while mitigating deleterious environmental impact (Mader et al., 2002) makes the 
use of biofertilisers a prefered alternative and feasible production practice in contrast to the use of inorganic fertilisers (Mena-Violante and Olade-Portugal, 2007).

Indications are that Trichoderma harzianum can improve the solubility of soil micronutrients, such as $\mathrm{Zn}, \mathrm{Cu}, \mathrm{Fe}, \mathrm{Mn}$ (Kaya et al., 2009) whereas arbuscular mycorrhizal fungi (AMF) enhance the uptake of $\mathrm{P}, \mathrm{N}$ and $\mathrm{K}$ (Cardoso and Kuyper, 2006). However, information regarding their combined effects on the phytochemical content, nutrient content and yield of tomato is inconsistent (Gosling et al., 2006), inadequate (Dumas et al., 2003) or simply lacking. The objective of this study was to determine the effect of tomato root inoculation with $T$. harzianum and AMF on fruit yield, fruit quality and nutrient content of tomato fruit produced in a greenhouse system.

\section{Materials and methods}

\subsection{Study location, microbial inoculants and seedling production}

This study was conducted under greenhouse conditions at the Hatfield Experimental Farm, University of Pretoria, South Africa during the 2009 growing season. The site is located at $23^{0}$ 45' S latitude, $28^{0} 16^{\prime}$ E longitude, at a $1372 \mathrm{~m}$ above sea level. Seeds of tomato cv. 'NemoNetta' were sown into cell plug trays filled with peatmoss, thoroughly mixed with the appropriate treatment and covered with vermiculite.

Commercial mycorrhizal inoculum Biocult ${ }^{\circledR}$ (Sommerset West, South Africa), containing spores of Glomus mosseae (40 spores $\mathrm{g}^{-1}$, as granulate) was obtained from Biocult Ltd. (Sommerset, South Africa), whereas commercial T. harzianum inoculum containing spores of $T$. harzianum isolate DB $103\left(1 \times 10^{9} \mathrm{CFU} \mathrm{g}^{-1}\right.$, as a wettable powder $)$ was obtained from Dagutat Biolab (Cape Town, South Africa).

Seedling trays were divided into three groups, with the first group being inoculated with

AMF that was thoroughly mixed with peatmoss at the rate of $10 \mathrm{~g} \mathrm{~kg}^{-1}$ peat before sowing. In the 
second group (two weeks later), AMF was applied in seedling trays before transplanting around the basal part of the plant. The last group, comprising untreated AMF, had the same amount of autoclaved inoculum applied. In addition, the non-AMF control received a $10 \mathrm{~mL}$ aliquot of AMF filtrate to establish similar microflaura communities. Each seedling tray group was later divided into three groups corresponding to T. harzianum application, which were (1) applied at sowing, (2) two weeks later or (3) untreated control. The inoculum was added to reach a population of $1.8 \times 10^{7}$ conidia $\mathrm{g}^{-1}$ peat.

\subsection{Experimental design and treatments}

Two weeks after sowing, seedlings were transplanted to 5 L-pot filled with an autoclaved sand coir mixture (ratio 2:1). The nine treatment combinations (3 T. harzianum $\times 3 \mathrm{AMF}), \mathrm{T}_{0} \mathrm{M}_{0}$ (uninoculated), $\mathrm{T}_{0} \mathrm{M}_{1}$ (treated with $\mathrm{AMF}$ only, before sowing), $\mathrm{T}_{0} \mathrm{M}_{2}$ (treated with $\mathrm{AMF}$ only, two weeks after sowing), $\mathrm{T}_{1} \mathrm{M}_{0}$ (treated with $T$. harzianum only, before sowing), $\mathrm{T}_{1} \mathrm{M}_{1}$ (treated with both fungi before sowing), $\mathrm{T}_{1} \mathrm{M}_{2}$ (treated with $T$. harzianum before and AMF two weeks

after sowing), $\mathrm{T}_{2} \mathrm{M}_{0}$ (treated with $T$. harzianum only, two weeks after sowing), $\mathrm{T}_{2} \mathrm{M}_{1}$ (treated with T. harzianum at two weeks after sowing and AMF before sowing) and $\mathrm{T}_{2} \mathrm{M}_{2}$ (treated with both fungi two weeks after sowing), were arranged in a completely randomised design with six replications. Plant pots were spaced at $0.4 \mathrm{~m}$ between plants in a double row with $1 \mathrm{~m}$ between rows. Plants were fertilised with half strength modified Hoagland's solution (Spomer et al., 1997) and watered daily.

\subsection{Data collection}

\subsubsection{Harvest}

Harvesting started at ten weeks after transplanting and was continued for ten successive weeks, with two harvests per week. Twenty fruit/replicate of colour stage six, using tomato colour chart standard (Kleur-stadia tomaten, Holland), were used for fruit quality analysis. Fruit 
were divided into two groups as representative samples for the two fruit quality analysis procedures with the first group being used for the determination of the macro-elements, whereas the second group was used for the analysis of antioxidant activity, vitamin $\mathrm{C}$, lycopene and total flavonol contents.

\subsubsection{Yield and yield components}

At each harvest, fruit of colour stage six were weighed for total yield determination. The marketable yield was calculated as the weight of the total number of the fruits per plant (total yield) minus the weight of small fruits $(<47 \mathrm{~mm})$ and unmarketable fruits (defects, disease or physiological disorders). Fruit diameter was measured with a digital caliper (Starreett, 727 Series, Athol, Massachusetts, USA) and divided into four categories, using Jones (1999) scale: extra-large $(>67 \mathrm{~mm})$, large $(54-67 \mathrm{~mm})$, medium $(47-54 \mathrm{~mm})$ and small $(<47 \mathrm{~mm})$.

\subsubsection{Fruit quality}

Phytochemical content in fruit analysis was performed at Limpopo Agro-food Technology Station, Polokwane, South Africa. Lycopene content was extracted from tomatoes with a hexaneacetone-ethanol (2:1:1) mixture using Sharma and Le Maguer's (1996) and Toor's et al. (2006) methods. Vitamin C content was measured by a Metrohm 670 titroprocessor (Metrohm Herisau, Switzerland) using the method of the Association of Official Analytical Chemists (AOAC, 1990; Toor et al., 2006). Antioxidant activity was estimated by the Trolox Equivalent Antioxidant Activity method (Miller and Rice-Evans, 1997). Flavonoid content was measured using a colorimetric assay (Zhishen et al., 1999). Total P, K, Ca and Mg were determined by microwave digestion followed by inductively coupled plasma-atomic emission spectroscopy (ICP-AES) (USEPA, 1986).

\subsection{Data analysis}


Data were subjected to two-way analysis of variance using SAS (SAS Institute Inc., Cary, NC, USA (2002-2003) with T. harzianum and AMF as treatments factors, each at three levels (untreated, at sowing, and two weeks later). The variance was related to the main effects and interactions between them. When F-ratio was significant, mean separation was achieved using Fisher's least significant difference test. Unless otherwise stated, treatments discussed were significantly different at 5\% level of probability.

\section{Results}

\subsection{Yield and yield components}

Main treatments and their interaction had no significant effect on the number of fruit, marketable yield and total yield of tomato per plant (Table 1). Both fungal inoculants increased the yield and marketable yield of tomato as compared to the untreated plants, $(\mathrm{P}>0.05)$. Mean comparison showed that the highest total yield $\left(8.2 \mathrm{~kg} \mathrm{plant}^{-1}\right)$ and marketable yield $(79.8 \%)$ were achieved with the combined inoculation of T. harzianum and AMF before seeding (Table $1)$.

Regardless of $T$. harzianum application, inoculating with AMF before sowing $\left(\mathrm{M}_{1}\right)$ increased the percentage of extra-large fruit by about $8 \%$ as compared to the uninoculated plants $\left(\mathrm{M}_{0}\right)$, which were similar to those inoculated with AMF two weeks after sowing $\left(\mathrm{M}_{2}\right)$. In terms of medium fruit, inoculating AMF before $\left(\mathrm{M}_{1}\right)$ or two weeks after sowing $\left(\mathrm{M}_{2}\right)$ decreased the percentage of fruit by about $23.6 \%$ and $15.5 \%$, respectively, when compared with uninoculated plants $\left(\mathrm{M}_{0}\right)($ Table 2$)$.

\subsection{Tomato fruit mineral content}

There was a significant effect of $T$. harzianum inoculation on $\mathrm{Ca}$ and $\mathrm{Mg}$ fruit contents (Table 3). Inoculating T. harzianum two weeks after sowing $\left(\mathrm{T}_{2}\right)$ decreased the fruit content of 
Ca by about $21 \%$ as compared to the uninoculated plants $\left(\mathrm{T}_{0}\right)$. Compared to the untreated plants, $\mathrm{Mg}$ content of fruit was significantly lowered (10\%) when $T$. harzianum was applied two weeks later. Mean comparison showed that the highest fruit content of $\mathrm{Mg}(15.3 \mathrm{mg} / 100 \mathrm{~g} \mathrm{FW})$ was achieved with early T. harzianum inoculation (Table 3).

\subsection{Phytochemical analysis}

Lycopene content was the only phytochemical that was significantly affected by main and interactive effects of T. harzianum and AMF application (Table 4). Inoculating T. harzianum and AMF before sowing $\left(\mathrm{T}_{1} \mathrm{M}_{1}\right)$ increased the lycopene content by about ca. $14 \%$ as compared to the uninoculated plants $\left(\mathrm{T}_{0} \mathrm{M}_{0}\right)$, which in turn was higher $(10 \%)$ than when both fungi were

applied two weeks after sowing $\left(\mathrm{T}_{2} \mathrm{M}_{2}\right)$ (Table 4). The highest lycopene content $(17.9 \mathrm{mg} / 100 \mathrm{~g}$ FW) was obtained with the combined application of $T$. harzianum and AMF, when simultaneously inoculated before sowing $\left(\mathrm{T}_{1} \mathrm{M}_{1}\right)$, whereas the lowest count $(9.5 \mathrm{mg} / 100 \mathrm{~g} \mathrm{FW})$ was obtained with late AMF, application in the absence of $T$. harzianum $\left(\mathrm{T}_{0} \mathrm{M}_{2}\right)$. Antioxidant activity, vitamin $\mathrm{C}$ and total flavonoid contents were not affected by T. harzianum and AMF inoculation (Table 5).

\section{Discussion}

In this study, non-significant increases in fruit yield and marketable fruit were observed. Enhanced yield and marketable yield had been reported with bacterial inoculants. For instance, inoculating tomato with Bacillus subtilus increased yield and marketable yield in tomato (MenaViolante and Olalde-Portugal, 2007). The two authors suggested that facilitating plant nutrition could be the mechanism through which this microbial inoculant enhanced crop yield. Bal and Altintas (2008) reported non-significant increases in lettuce yield with T. harzianum inoculation. Similarly, Bal and Altintas (2006) did not observe an increase in fruit yield of tomato. Contrary 
to Salvioli et al. (2008) who reported improved tomato yield following mycorrhizal inoculation, Kaya et al. (2009) observed similar effect only when AMF was applied on salt-stressed tomato plants. Fruit size is an important factor for fresh produce marketing. In this study, AMF significantly increased the percentage of extra-large fruit. Similar results were reported with pepper inoculated with different plant growth-promoting rhizobacteria (PGPR) strains (Vavrina, 1999; Mena-Violante and Olalde-Portugal, 2007). The increased fruit size observed during this study could be associated with triggering of molecules or enzymes responsible for modulating tomato fruit cell expansion. In particular, sucrose synthase is thought to play a central role in developing tomato fruits (D'Aoust et al., 1999; Carrari and Fernie, 2006), whereas auxins have been suggested to promote fruit cell expansion by causing an increase in cell wall extensibility (Gillaspy et al., 1993; Catalá et al., 2000). Increased root auxins after mycorrhizal inoculation have been reported for maize (Ludwig-Müller and Güther, 2007).

The role of AMF on the uptake of $\mathrm{P}$ is well-documented in the literature. Phosphorus is believed to help increase the number of blossoms during early growth and early fruit set (Zobel, 1966; Sainju et al., 2003), thus, increasing tomato fruit yield (Sainju et al., 2003). During the course of this experiment, the fruit $\mathrm{P}$ content in all the treatments was similar. In the present study, fertiliser was applied thus AMF inoculation would not necessarily increase P content. Contrary to $\mathrm{P}$ content of the fruit, the findings of this study showed that $T$. harzianum might have a detrimental effect on the uptake of $\mathrm{Ca}$ and $\mathrm{Mg}$, as both nutrients were significantly reduced in fruits when $T$. harzianum was applied two weeks after sowing. The low transport of these nutrients to the fruit could be due to ion interactions in the root zone (Shear, 1975; Schimanski, 1981). .

Although information on the effect of microbial inoculants on phytochemical content of tomato fruit is scarce, results in this study clearly demonstrated that $T$. harzianum and AMF can play a minor role in their accumulation in tomato fruit. The antioxidant content of tomato, which depends on genetic and environmental factors and varies over the ripening stage (Hart and Scott, 
1995; Javanmardi and Kubota, 2006) was not affected by AMF and T. harzianum. Similarly, vitamin $\mathrm{C}$ and total flavonol contents in fruit remained unchanged regardless of T. harzianum or AMF inoculation. However, lycopene content was increased by both T. harzianum and AMF inoculation, which was in agreement with Ulrichs et al. (2008), who found an increased lycopene content in tomato fruit due to AMF inoculation. Another plausible explanation could be that lycopene, which develops rapidly in fruit in darker conditions such as those protected by crop foliage (Soto-Zamora et al., 2005; Javanmardi and Kubota, 2006) has increased due to the higher plant biomass (data not shown) of fungi-inoculated plants observed during the trial.

In conclusion, T. harzianum and AMF have negligible influences on yield of tomato. The slight increase in the percentage of extra-large fruit, suggest that these fungal inoculants likely have biofertiliser effects on tomato production. Nutrient and phytochemical contents varied depending on the inoculation time. Generally, inoculation with T. harzianum two weeks after sowing lowered the fruit $\mathrm{Ca}, \mathrm{Mg}$ while late inoculation with $\mathrm{AMF}$ lowered lycopene content of tomato fruit. The findings of this study suggest an early inoculation with T. harzianum and AMF for an improved tomato fruit quality.

\section{References}

Ahmed, L., Martin-Diana, A.B., Rico, D., Barry-Ryan, C., 2010. The antioxidant properties of whey permeate treated fresh-cut tomatoes. Food Chem. Article in press.

AOAC International, 1990. Official Methods of Analysis, $15^{\text {th }}$ ed. Association of Official Analytical Chemists, Washington, D.C

Bal, U., Altintas, S., 2006. Effects of Trichoderma harzianum on the yield and fruit quality of tomato plants (Lycopersicon esculentum) grown in an unheated greenhouse. Aust. J. Exp. Agr. 46, 131-136. 
Bal, U., Altintas, S., 2008. Effect of Trichoderma harzianum on lettuce in protected cultivation. J. Cent. Eur. Agr. 9, 63-70.

Cardoso, I.M., Kuyper, T.W., 2006. Mycorrhizas and tropical soil fertility. Agr. Ecosyst. Environ. 116, 72-84.

Carrari, F., Fernie, A.R., 2006. Metabolic regulation underlying tomato fruit development. J. Exp. Biol. 57, 1883-1897.

Catalá, C., Rose, J.K.C., Bennett, A.B., 2000. Auxin-regulated genes encoding cell wallmodifying proteins are expressed during early tomato fruit growth. Plant Physiol. $122,527-534$.

Chapagain, B.P., Wiesman, Z., 2004. Effect of potassium magnesium chloride in the fertigation solution as partial source of potassium on growth, yield and quality of greenhouse tomato. Sci. Hortic-Amsterdam 99, 279-288.

Cooper, T., Bangerth, F., 1976. The effect of calcium and magnesium treatment on the physiology, chemical composition and bitter-pit development of "Cox orange" apples. Sci. Hortic-Amsterdam 5, 49-57

D'aoust, M.A., Yelle, S., Nguyen-Quoc, B., 1999. Antisense inhibition of tomato fruit sucrose synthase decreases fruit setting and the sucrose unloading capacity of young fruit. Plant Cell 11, 2407-2418.

Dorais, M., Ehret, D.L., Papadopoulos, A.P., 2008. Tomato (Solanum lycopersicum) health components: from the seed to the consumer. Phytochem. Rev.7, 231-250.

Dumas, Y., Dadomo, M., Lucca, G., Grolier, P., Di Lucca, G., 2003. Effects of environmental factors and agricultural techniques on antioxidant content of tomatoes. J. Sci. Food Agr. 83, 369-382.

FAO, 2010. Website database. http//www.fao.org

Flores, F.B., Sanchez-Bel, P., Estan, M.T., Martinez-Rodriguez, M.M., Moyano, E., Morales, B., Campos, J.F., Garcia-Abellán, Egea, M.I., Fernández-Garcia, N., Romojaro, F., 
Bolarín, M., 2010. The effectiveness of grafting to improve tomato fruit quality. Sci Hortic-Amsterdam 125, 211-217.

Gillaspy, G.H., Ben-David, H., Gruissem, W., 1993. Fruits: a developmental perspective. Plant Cell 5, 1439-1451.

Gosling, P., Hodge, A., Goodlass, G., Bending, G.D., 2006. Arbuscular mycorrhizal fungi and organic farming. Agr. Ecosyst. Environ.113, 17-35.

Gruda, N., 2005. Impact of environmental factors on product quality of greenhouse vegetables for fresh consumption. Crit. Rev. Plant Sci. 24, 227-247.

Hart, D.J., Scott, K.J., 1995. Development and evaluation of an HPLC method for the analysis of carotenoids in foods, and the measurement of the carotenoid content of vegetables and fruits commonly consumed in the U.K. Food Chem. 54, 101-111.

Hauffman, S., Bruce, Å., 2002. Matens kvalitet. Kungl Skogs- och Lantbruksakademien 1-15

Heber, D., 2000. Colorful cancer prevention: alpha-carotene, lycopene and lung cancer Am. J. Clin. Nutr.72, 901-902.

Heeb, A., 2005. Organic or mineral fertilization. Effects on tomato plant growth and fruit quality. Doctoral Thesis. Swedish University of Agricultural Sciences, Uppsala.

Javanmardi, J., Kubota, C., 2006. Variation of lycopene, antioxidant activity, total soluble solids and weight loss of tomato during postharvest storage. Postharvest Biol. Tec. 41, $151-155$.

Jones, J.B., 1999. Tomato plant culture: In the field, greenhouse, and home garden. CRC Press LLC, Florida. 11-53.

Kaya, C., Ashraf, M., Sonmez, O., Aydemir, S., Tuna, A.L., Cullu, M.A., 2009. The influence of arbuscular mycorrhizal colonization on key growth parameters and fruit yield of pepper plants grown at high salinity. Sci Hortic-Amsterdam 121, 1-6.

Lester, G.E., 2006. Environmental regulation of human health nutrients (ascorbic acid, carotene, and acid folic) in fruits and vegetables. Hortscience 41, 59-74. 
Ludwig-Müller, J., Güther, M., 2007. Auxins as signals in arbuscular mycorrhiza formation. Plant Signal. Behav. 3, 194-196.

Mader, P., Fliebach, A., Dubois, D., Gunst, L., Fried, P., Niggli, U., 2002. Soil fertility and biodiversity in organic farming. Science 296, 1694-1697.

Mena-Violante, H.G., Olalde-Portugal, V., 2007. Alteration of tomato fruit quality by root inoculation with plant growth-promoting rhizobacteria (PGPR): Bacillus subtilus BEB-13bs. Sci Hortic-Amsterdam 113, 103-106.

Miller, N.J., Rice-Evans, C.A., 1997. Factors influencing the antioxidant activity determined by the $\mathrm{ABTS}^{+}$radical cation assay. Free Radical Res. 26, 195-199.

Mozafar, A., 1994. Plant vitamins: agronomic, physiological, and nutritional aspects. CRC Press, Boca Raton.

Odriozola-Serrano, I., Soliva-Fortuny, R., Hernandez-Jover, T., Martin-Belloso, O., 2009. Carotenoid and phenolics profile of tomato juices processed by high intensity pulse electric fields compared with conventional thermal treatments. Food Chem.112, 258-266.

Paiva, E.A.S., Sampaio, R.A., Martinez, H.E.P., 1998. Composition and quality of tomato fruit cultivated in nutrient solution containing different calcium concentrations. J. Plant Nutr. 21, 2653-2661.

Rao, A.V., Agarwal, S., 2000. Role of antioxidant lycopene in cancer and heart disease. J. Am. Coll. Nutr. 19, 563-569.

Salvioli, A., Novero M., Lacourt, I., Bonfante, P., 2008. The impact of mycorrhizal symbiosis on tomato fruit quality. 16th IFOAM Organic World Congress, Modena, Italy

Sainju, U.M., Dries, R., Singh, B., 2003. Mineral nutrition of tomato. J.Food Agr. Environ. 1, 176-183.

SAS Institute, 2003. Statistical Analysis Systems Computer Package, Cary, New York, USA. 
Schimanski, C., 1981. The influence of certain experimental parameters on the flux characteristics of Mg-28 on the case of barley seedlings grown in hydroculture. Landwirt. Forsch. 34, 154-165.

Sharma, S.K., Le Maguer, M., 1996. Lycopene in tomatoes and tomato pulp fractions. Ital. J. Food Sci. 8, 107-113.

Shear, C.B., 1975. Calcium-related disorders of fruits and vegetables. HortScience 10, 361-365. Soto-Zamora, G., Yahia, E.M., Brecht, J.K., Gardea, J.K., 2005. Effects of postharvest hot air treatments on the quality and antioxidant levels in tomato fruit. Lebensm Wiss Technol. 38, 657-663.

Spomer L.A., Berry W.L., Tibbitts T.W., 1997. Plant culture in solid media. Plant growth chamber handbook. R.W Langham and T.W Tibbitts (Eds.). Iowa Agriculture and Home Economics Experiment Station Special Report.

Súarez, M.H., Rodriguez, E.M.R., Romero, C.D., 2008. Chemical composition of tomato (Lycopersicon esculentum) from Tenerife, the Canary Islands. Food Chem. 106, $1046-1056$

Toor, R.K., Savage, G.P., 2005. Antioxidant activity in different fractions of tomatoes. Food Res. Int. 38, 487-494.

Toor, R.K., Savage, G.P., Heeb, A., 2006. Influence of different types of fertilisers on the major antioxidant components of tomatoes. J. Food Comp. Anal. 19, 20-27.

Trudel, M.J., Ozbun, J.L., 1971. Influence of potassium on carotenoid content of tomato fruit. J. Am. Soc. Hortic. Sci. 96, 763-765.

Ulrichs, C., Fischer, G., Büttner, C., Mewis, I., 2008. Comparison of lycopene, $\beta$-carotene and phenolic contents of tomato using conventional and ecological horticultural practices, and arbuscular mycorrhizal fungi (AMF). Agron. colomb. 26, 1-12 
USEPA, 1986. Method 3051. Acid digestion of sediments, sludges and soils. In: Tests Methods or Evaluating Solid Waste, vol IA: EPA/SW-846, $3^{\text {rd }}$ ed. National Technical Information Service, Springfield, VA.

Vavrina, C.S., 1999. Plant Growth promoting Rhizobacteria via a Transplant Plug Delivery System in the Production of Dril Irrigated Pepper. SWFREC Station ReportVEG99.6. University of Florida, FL.

Wilcox, J.K., Catignani, G.L., Lazarus, C., 2003. Tomatoes and cardiovascular health. Crit. Rev. Food Sci. 43, 1-18.

Zhishen, J., Mengcheng, T., Jianming, W., 1999. The determination of flavonoid contents in mulberry and their scavenging effects on superoxide radicals. Food chem. 64, 555-559.

Zobel, M.B., 1966. Mechanization of tomato production. Proc. National Conference on Tomatoes. Department of Horticulture, Perdue University, National Canners Association, Lafayette. 
Table 1. Yield and marketable yield of tomato as influenced by T. harzianum and AMF inoculation $\left(\mathrm{T}_{0}=\right.$ no $T$. harzianum applied; $\mathrm{T}_{1}=T$. harzianum before sowing; $\mathrm{T}_{2}=T$.

harzianum two weeks after sowing; $\mathrm{M}_{0}=$ no AMF applied; $\mathrm{M}_{1}=\mathrm{AMF}$ before sowing; $\mathrm{M}_{2}=\mathrm{AM}$ two weeks after sowing).

Response variable No. fruit/plant Yield/plant (kg) Marketable yield/plant (\%)

$\begin{array}{llll}\mathrm{T}_{0} \mathrm{M}_{0} & 138.2 \pm 11.9 & 7.2 \pm 1.0 & 75.4 \pm 6.9 \\ \mathrm{~T}_{0} \mathrm{M}_{1} & 147.3 \pm 15.9 & 7.6 \pm 1.4 & 76.4 \pm 8.3 \\ \mathrm{~T}_{0} \mathrm{M}_{2} & 143.0 \pm 22.1 & 7.5 \pm 1.6 & 76.4 \pm 8.6 \\ \mathrm{~T}_{1} \mathrm{M}_{0} & 139.6 \pm 21.8 & 7.3 \pm 1.7 & 75.2 \pm 10.9 \\ \mathrm{~T}_{1} \mathrm{M}_{1} & 148.1 \pm 12.1 & 8.2 \pm 0.7 & 79.8 \pm 6.7 \\ \mathrm{~T}_{1} \mathrm{M}_{2} & 145.8 \pm 15.7 & 8.0 \pm 0.9 & 77.4 \pm 6.6 \\ \mathrm{~T}_{2} \mathrm{M}_{0} & 137.7 \pm 18.0 & 7.4 \pm 1.8 & 76.0 \pm 7.4 \\ \mathrm{~T}_{2} \mathrm{M}_{1} & 140.3 \pm 28.5 & 8.0 \pm 1.2 & 79.4 \pm 8.5 \\ \mathrm{~T}_{2} \mathrm{M}_{2} & 140.1 \pm 26.6 & 7.7 \pm 1.1 & 77.5 \pm 9.4\end{array}$

Source of variation

$\begin{array}{llll}T . \text { harzianum (T) NS } & \text { NS } & \text { NS } \\ \text { AMF (M) } & \text { NS } & \text { NS } & \text { NS } \\ \text { T } \times \text { M } & \text { NS } & \text { NS } & \text { NS }\end{array}$

NS: not significant, $P \leq 0.05$. 
Table 2. Fruit size of tomato as influenced by T. harzianum and AMF inoculation $\left(\mathrm{T}_{0}=\right.$ no T. harzianum applied; $\mathrm{T}_{1}=T$. harzianum before sowing; $\mathrm{T}_{2}=T$. harzianum two weeks after sowing; $\mathrm{M}_{0}=$ no AMF applied; $\mathrm{M}_{1}=$ AMF before sowing; $\mathrm{M}_{2}=$ AMF two weeks after sowing).

Response variable Extra-large fruit (\%) Large fruit (\%) Medium fruit (\%) Small fruit (\%) T. harzianum (T)

$\begin{array}{lllll}\mathrm{T}_{0} & 45.4 \mathrm{a} \pm 5.8 & 29.5 \mathrm{a} \pm 6.5 & 14.1 \mathrm{a} \pm 3.7 & 10.9 \mathrm{a} \pm 3.5 \\ \mathrm{~T}_{1} & 45.0 \mathrm{a} \pm 6.9 & 30.2 \mathrm{a} \pm 7.5 & 14.7 \mathrm{a} \pm 4.8 & 10.2 \mathrm{a} \pm 3.7 \\ \mathrm{~T}_{2} & 44.6 \mathrm{a} \pm 8.9 & 32.4 \mathrm{a} \pm 7.1 & 13.2 \mathrm{a} \pm 6.2 & 9.9 \mathrm{a} \pm 3.4\end{array}$

$\operatorname{AMF}(\mathrm{M})$

$\begin{array}{lllll}\mathrm{M}_{0} & 42.4 \mathrm{~b} \pm 8.2 & 31.4 \mathrm{a} \pm 7.6 & 16.1 \mathrm{a} \pm 5.8 & 10.1 \mathrm{a} \pm 3.3 \\ \mathrm{M}_{1} & 46.5 \mathrm{a} \pm 6.3 & 30.9 \mathrm{a} \pm 6.4 & 12.3 \mathrm{~b} \pm 3.5 & 10.2 \mathrm{a} \pm 3.8 \\ \mathrm{M}_{2} & 46.5 \mathrm{a} \pm 6.6 & 29.7 \mathrm{a} \pm 7.2 & 13.6 \mathrm{~b} \pm 4.7 & 10.6 \mathrm{a} \pm 3.2\end{array}$

Source of variation

T. harzianum (T) NS AMF (M)

$\mathrm{T} \times \mathrm{M}$

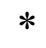

NS
NS

NS

NS
NS

$*$

NS
NS

NS

NS

Means within column followed by the same letter were not significantly different $(P \leq 0.05)$ according to Fisher's LSD test.NS, *, are levels of significance (not significant, $P \leq 0.05$, respectively). 
Table 3. Chemical fruit contents of tomato as influenced by T. harzianum and AMF inoculation $\left(\mathrm{T}_{0}=\right.$ no $T$. harzianum applied; $\mathrm{T}_{1}=T$. harzianum before sowing; $\mathrm{T}_{2}=T$. harzianum two weeks after sowing; $\mathrm{M}_{0}=$ no AMF applied; $\mathrm{M}_{1}=\mathrm{AMF}$ before sowing; $\mathrm{M}_{2}=\mathrm{AM}$ two weeks after sowing).

$\begin{array}{ccccc}\begin{array}{c}\text { Response } \\ \text { variable }\end{array} & \mathrm{P}(\mathrm{mg} / 100 \mathrm{~g} & \mathrm{K}(\mathrm{mg} / 100 \mathrm{~g} & \mathrm{Ca}(\mathrm{mg} / 100 \mathrm{~g} & \mathrm{Mg}(\mathrm{mg} / 100 \mathrm{~g} \\ & \mathrm{FW}) & \mathrm{FW}) & \mathrm{FW}) & \mathrm{FW})\end{array}$

T. harzianum (T)

$\begin{array}{lllll}\mathrm{T}_{0} & 0.35 \mathrm{a} \pm 0.04 & 185.7 \mathrm{a} \pm 18.6 & 12.7 \mathrm{~b} \pm 1.2 & 14.2 \mathrm{ab} \pm 1.2 \\ \mathrm{~T}_{1} & 0.37 \mathrm{a} \pm 0.08 & 157.6 \mathrm{ab} \pm 39.5 & 11.9 \mathrm{ab} \pm 2.4 & 15.3 \mathrm{a} \pm 2.5 \\ \mathrm{~T}_{2} & 0.34 \mathrm{a} \pm 0.05 & 162.8 \mathrm{ab} \pm 38.9 & 10.4 \mathrm{~b} \pm 2.3 & 12.9 \mathrm{~b} \pm 1.5\end{array}$

$\operatorname{AMF}(\mathrm{M})$

$\begin{array}{lllll}\mathrm{M}_{0} & 0.34 \mathrm{a} \pm 0.04 & 184.7 \mathrm{a} \pm 13.1 & 10.4 \mathrm{a} \pm 2.2 & 14.7 \mathrm{a} \pm 1.5 \\ \mathrm{M}_{1} & 0.39 \mathrm{a} \pm 0.06 & 180.0 \mathrm{a} \pm 26.5 & 12.6 \mathrm{a} \pm 1.8 & 14.7 \mathrm{a} \pm 1.8 \\ \mathrm{M}_{2} & 0.33 \mathrm{a} \pm 0.06 & 141.3 \mathrm{a} \pm 42.1 & 12.0 \mathrm{a} \pm 2.2 & 13.1 \mathrm{a} \pm 2.5\end{array}$

Source of variation

$\begin{array}{lllll}\mathrm{T} & \mathrm{NS} & \mathrm{NS} & * & * \\ \mathrm{M} & \mathrm{NS} & \mathrm{NS} & \mathrm{NS} & \mathrm{NS} \\ \mathrm{T} \times \mathrm{M} & \mathrm{NS} & \mathrm{NS} & \mathrm{NS} & \text { NS }\end{array}$

Means within column followed by the same letter were not significantly different $(P \leq 0.05)$ according to Fisher's LSD test.NS, *, are levels of significance (not significant, $P \leq 0.05$, respectively). 
Table 4. Lycopene content of tomato fruit as influenced by the interactive effect of Trichoderma harzianum and arbuscular mycorrhizal fungi (AMF) inoculation $\left(\mathrm{T}_{0}=\right.$ no $T$. harzianum applied; $\mathrm{T}_{1}=T$. harzianum before sowing; $\mathrm{T}_{2}=T$. harzianum two weeks after sowing; $\mathrm{M}_{0}=$ no AMF applied; $\mathrm{M}_{1}=\mathrm{AMF}$ before sowing; $\mathrm{M}_{2}=\mathrm{AM}$ two weeks after sowing).

\begin{tabular}{|c|c|c|}
\hline \multirow{2}{*}{ Treatment } & \multicolumn{2}{|c|}{ Lycopene (mg/100 g FW) } \\
\hline & $\mathrm{M}_{0}$ & $\mathrm{M}_{2}$ \\
\hline $\mathrm{T}_{0}$ & $15.5 \mathrm{ab} \pm 1.617 .8 \mathrm{a} \pm 0.1$ & $9.5 b \pm 3.8$ \\
\hline $\mathrm{T}_{1}$ & $16.1 \mathrm{a} \pm 1.2 \quad 18.0 \mathrm{a} \pm 0.4$ & $16.7 a \pm 1.6$ \\
\hline $\mathrm{T}$ & $14.8 \mathrm{ab} \pm 0.614 .1 \mathrm{ab} \pm 1$ & $13.9 \mathrm{ab} \pm 4.0$ \\
\hline
\end{tabular}

Source of variation Df ANOVA SS Mean square $F$ value $P$

$\begin{array}{llllll}\mathrm{T} & 2 & 41.8 & 20.9 & 4.70 & 0.023 \\ \mathrm{M} & 2 & 49.8 & 24.9 & 5.59 & 0.012 \\ \mathrm{~T} \times \mathrm{M} & 4 & 68.1 & 17.0 & 3.82 & 0.020\end{array}$

Means within column followed by the same letter were not significantly different $(P \leq 0.05)$ according to Fisher's LSD test. 
Table 5. Antioxidant activity, vitamin $\mathrm{C}$ and total flavonoids contents of tomato fruit as influenced by $\mathrm{T}$. harzianum and AMF inoculation $\left(\mathrm{T}_{0}=\right.$ no $\mathrm{T}$. harzianum applied; $\mathrm{T}_{1}=\mathrm{T}$. harzianum before sowing; $\mathrm{T}_{2}=\mathrm{T}$. harzianum two weeks after sowing; $\mathrm{M}_{0}=$ no AMF applied; $\mathrm{M}_{1}=\mathrm{AMF}$ before sowing; $\mathrm{M}_{2}=\mathrm{AM}$ two weeks after sowing).

$\begin{array}{cccc}\begin{array}{c}\text { Response } \\ \text { variable }\end{array} & \begin{array}{c}\text { Antioxidant activity }(\mathrm{mg} \\ \text { Trolox/l) }\end{array} & \begin{array}{c}\text { Vitamin } \mathrm{C}(\mathrm{mg} / 100 \mathrm{~g} \\ \mathrm{FW})\end{array} & \begin{array}{c}\text { Total flavonoids } \\ \left({ }^{\mathbf{a}} \mathrm{RE} / 100 \mathrm{~g} \mathrm{FW}\right)\end{array}\end{array}$

$\begin{array}{llll}\mathrm{T}_{0} \mathrm{M}_{0} & 5.1 \pm 0.1 & 24.7 \pm 1.5 & 0.26 \pm 0.03 \\ \mathrm{~T}_{0} \mathrm{M}_{1} & 5.1 \pm 0.2 & 23.3 \pm 2.1 & 0.28 \pm 0.05 \\ \mathrm{~T}_{0} \mathrm{M}_{2} & 5.1 \pm 0.1 & 20.3 \pm 0.6 & 0.26 \pm 0.06 \\ \mathrm{~T}_{1} \mathrm{M}_{0} & 5.1 \pm 0.2 & 26.3 \pm 1.5 & 0.21 \pm 0.11 \\ \mathrm{~T}_{1} \mathrm{M}_{1} & 5.0 \pm 0.1 & 25.0 \pm 5.6 & 0.28 \pm 0.03 \\ \mathrm{~T}_{1} \mathrm{M}_{2} & 5.0 \pm 0.1 & 28.0 \pm 4.3 & 0.21 \pm 0.09 \\ \mathrm{~T}_{2} \mathrm{M}_{0} & 5.1 \pm 0.3 & 25.3 \pm 3.5 & 0.20 \pm 0.12 \\ \mathrm{~T}_{2} \mathrm{M}_{1} & 5.0 \pm 0.1 & 22.0 \pm 1.0 & 0.21 \pm 0.08 \\ \mathrm{~T}_{2} \mathrm{M}_{2} & 5.0 \pm 0.2 & 25.0 \pm 5.0 & 0.21 \pm 0.10\end{array}$

Source of variation

$\begin{array}{llll}\mathrm{T} & \mathrm{NS} & \mathrm{NS} & \mathrm{NS} \\ \mathrm{M} & \mathrm{NS} & \mathrm{NS} & \mathrm{NS} \\ \mathrm{T} \times \mathrm{M} & \mathrm{NS} & \mathrm{NS} & \mathrm{NS}\end{array}$

NS: not significant, $\mathrm{P} \leq 0.05$.

${ }_{-}^{\mathrm{a}} \mathrm{RE}$ : rutin equivalent. 